\title{
The Swazi Press and its Contribution to Good Governance
}

\author{
Richard Charles Rooney
}

Abstract: This paper audits the newspapers of Swaziland in the context of their abilities to encourage and foster good governance. Swaziland, a non-democracy with an ailing economy, severe poverty and the highest HIV/AIDS rate in the world, is in crisis. Freedoms of the press, expression and association are restricted.

The paper sets out four research questions: (i) How pluralistic is media ownership? (ii) How independent are the media from government? (iii) How representative are the media of different opinions and how accessible are they to different sections of society, including poor and vulnerable groups and political parties? (iv) What are the capacities of Swazi journalists and where might there be areas for development?

The paper utilizes a content analysis of the editorial of the kingdom's two daily newspapers identifying the main news agendas and also the sources of information that journalists rely on for their reports. In addition, contributions from journalistic practitioners give valuable insights into the realities of working in the media under restrictions.

The paper concludes that there is much still to be done in Swaziland before the news media can be said to be fully contributing to fostering and encouraging good governance in the kingdom.

Email: rooney@uniswacc.uniswa.sz dickrooney@hotmail.com

Mailing address: University of Swaziland, Private Bag 4, Kwaluseni, Swaziland. Telephone: (268) 5184011 ext2121 (office).

Introduction

Swaziland, the smallest nation on the African continent and the only one in sub-Sahara to be ruled by an absolute monarch, is in a crisis of governance. Corruption is rife, the economy is ailing and the population has the highest rate of HIV/AIDS infection of anywhere in the world.

Freedoms of the press, expression and association are restricted, but as a result of internal and external pressures the kingdom is being forced to consider its governance structures.

This paper does not intend to give a detailed account of the governance issues in the nondemocratic kingdom but rather it uses this as a context to undertake an audit of the contribution the Swazi press plays in encouraging good governance in Swaziland.

The paper begins with a general overview of the kingdom and defines "good governance" before setting out four research questions: (i) How pluralistic is media ownership? (ii) How independent are the media from government? (iii) How representative are the media of different opinions and how accessible are they to different sections of society, including poor and vulnerable groups and political parties? (iv) What are the capacities of Swazi journalists and where might there be areas for development? 
The paper utilizes a content analysis of the editorial of the kingdom's two daily newspapers identifying the main news agendas and also the sources of information that journalists rely on for their reports. In addition, contributions from journalistic practitioners give valuable insights into the realities of working in the media under restrictions.

The paper concludes that there is much still to be done in Swaziland before the news media can be said to be fully contributing to fostering and encouraging good governance in the kingdom.

\section{Swaziland background}

One cannot divorce the kingdom's media from the kingdom itself. Swaziland is the smallest country on the continent of Africa and is landlocked with borders to South Africa and Mozambique. The population of 1.1 million people is ethnically homogeneous and approximately 97 percent of the people are Swazi. Most of this population is rural with only 23 percent living in urban or suburban areas.

Swazis are religious with about 55 percent of the population belonging to protestant groups; Muslims make up 10 percent; Roman Catholics, 5 percent; and those that subscribe to the indigenous belief, 30 percent (Olaleye 2003, p.6).

Swaziland is not a democracy. The kingdom is ruled by King Mswati III, an absolute monarch, and since 1973 the country has been under a state of emergency following a Royal Proclamation. A new constitution that underpins the position of the monarch and leaves political parties banned came into force in February 2006. It is as yet unclear whether the signing of the constitution will encourage some form of democracy in the kingdom but there are reasons to be pessimistic. There was controversy surrounding the constitution and its writing as only individual members of the public were allowed to make submissions on its drafting, thereby excluding all civil society groups from the process (International Crisis Group 2005, p.4).

The economy is in decline and about two thirds of the population live below the poverty line on less than US\$7 per month. Around one half of the population rely on food assistance from international agencies and HIV infection rates are the highest in the world.

The population of the kingdom aged over 15 years who can read and write, is estimated at 78 per cent.

In terms of its governance Swaziland is considered to be far behind the rest of the southern African region (Ibid, pp.10-12). As a consequence of this the European Union announced in May 2006 that it would suspend direct funding to Swaziland because of the kingdom's poor accounting and auditing mechanisms (Ndlovu 2006).

\section{Identifying "good governance”}

The term governance occupies a central position in international policy discourse, but there are many definitions of "governance". These definitions range from the manner in which power is exercised in the management of a country's economic and social resource (World Bank); the exercise of economic, political and administrative authority to manage a country's 
affairs (United Nations Development Programme) and the sum of the many ways individuals and institutions, public and private, manage their common affairs (Commission on Global Governance) (Feustel et al, n.d.).

Feustel et al extract key elements associated with the term "governance" that are useful for the purposes of this paper. Firstly, governance should not be equated with government: it includes government but goes further to include other actors in the public realm. Nonetheless, the main focus of governance remains on the state.

Secondly, governance is mainly used in reference to the "good governance" paradigm, a reaction to two negative characteristics of national systems: the unrepresentative character of governments and the inefficiency of non-market systems.

Although good governance has no precise normative connotations there is a widespread agreement about many of its characteristics. Typical of these are the seven key good governance capabilities identified by the UK government's Department for International Development (DfID 2001).

Operate political systems which provide opportunities for all the people, including the poor and disadvantaged to influence government policy and practice.

Provide macroeconomic stability and to facilitate private sector investment and trade so as to promote the growth necessary to reduce poverty.

Implement pro-poor policy and to raise, allocate and account for public resources accordingly.

Guarantee the equitable and universal provision of effective basic services.

Ensure personal safety and security with access to justice for all.

Manage national security arrangements accountably and to resolve differences between communities before they develop into violent conflicts.

Develop honest and accountable government that can combat corruption. (Ibid, p.9)

Recent worldwide consultations with poor people revealed their inability to access public services because of pervasive corruption, of the lack of public security and personal safety, of the oppressive behavior of the police and judiciary who ought to protect them and of their general sense of powerlessness (Ibid, p.9).

\section{The importance of news media to good governance}

This paper explores the relationship between the Swazi press and the extent to which the kingdom's two daily newspapers contribute to achieving good governance in Swaziland.

Today, there is a wide geopolitical consensus that political systems should exist to provide opportunities for all the people to influence government and practice (DfID, 2001) and that the media reinforce or foster this kind of democracy (Price \& Krug 2002, p.3). 
There is always a degree of tension between government and media, even in democracies with a long tradition of media freedom. On the one hand the government is responsible for regulating the media and on the needs to use the media to communicate with the public (Roth 2001, p.10).

On the other hand, the media have a prime responsibility to examine what government is and is not doing, by reporting the news, interpreting the news, influencing citizens' opinions, setting the agenda for government action, and socializing citizens about politics and encouraging a political culture to evolve (Roth 2001, p.10; Ojo 2003, p.828).

To engage effectively there is an assumption that access to information is the first requirement for an engaged, participative democracy (Roth 2001, p.13). An active citizenry will help prevent governmental excesses and breed trust in the democratic system, thereby enabling the private media to perform their functions (Tetty 2003, p.28) and the media are the major mechanisms by which citizens are informed about the world (Sparks 1991). There are specific public interest political goals which the media can be used to serve, including the following: informing the public, public enlightenment, social criticism and exposing government arbitrariness, national integration and political education. But the more the media serve the narrow self interest the less able they are to serve the other group of public interests (Ojo 2003, pp.829-830).

In a free market, media are said to be agencies of information and debate which facilitate the functions of democracy. For Jurgan Habermas (1989) the free market allows anyone to publish an opinion and ensures all points of view are aired. But, as James Curran summarises, there are restrictions to this model which are the by-product of treating information as a commodity: i) the high costs of entry into the market, ii) the free market restricts participation in public debate. It generates an information rich media for elites and information poor media for the general public. iii) it undermines rational debate by generating information that is simplified, personified and decontextualised (Curran 2002, p.226).

To investigate the extent to which Swazi's news media contributes to good governance this paper will explore four questions.

How pluralistic is media ownership?

How independent are the media from government?

How representative are the media of different opinions and how accessible are they to different sections of society, including poor and vulnerable groups and political parties?

What are the capacities of Swazi journalists and where might there be areas for development?

How pluralistic is media ownership?

The majority of the Swazi news media is state controlled and that small part that is in private hands has been subjugated to the needs of the monarchy. There are two principal players in the newspaper sector that have been in control for the past 35 years. The first is the Loffler family based in Namibia that owns African Echo, the holding company of the daily Times of Swaziland, Swazi News (published Saturday) and the Times Sunday. These newspapers, the 
first of which, the Times, was established in 1897, are the only major news sources in the kingdom free of government control (SADC 2004, pp.45-47).

The second major player is the corporation Tibiyo Taka Ngwane, which is controlled by the Swazi royal family and owns the Observer Media Group, which publishes the Swazi Observer and its stablemate, the Weekend Observer. Both were temporarily closed in 2002 because in spite of their royal connections the editorial direction was seen as becoming increasingly liberal.

One independent monthly comment magazine, the Nation Magazine, manages to continue publishing despite government opposition and a small circulation. A free government produced newssheet, Swaziland Today, has very little credibility.

There are two free-to-air television stations in Swaziland, the Swaziland Television Authority (STA) and Channel Swazi. The STA is the state broadcaster and still dominates airwaves. Two acts of parliament have resulted in a monopoly by state owned radio and television. Broadcast licensing is the prerogative of Swaziland Posts and Telecommunications which has the sole authority to issue licenses (Maziya 2003, p.91).

The STA has one channel with multiple national repeaters. The government recently allowed Channel Swazi, a pro-establishment medium, to begin operating domestically (SADC 2004, pp.45-47).

The South Africa-based satellite broadcaster MultiChoice also operates in Swaziland, providing subscribers with access to television services including Cable News Network $(\mathrm{CNN}), \mathrm{BBC}$ and Sky News.

There are two radio broadcasters in Swaziland: the Swaziland Broadcasting and Information Services and Voice of the Church, a private Christian radio station which is a local franchise of TransWorld Radio. Voice of the Church is the only privately-owned radio station in Swaziland. The Swaziland Broadcasting and Information Services is a state-run national radio service. It has one siSwati language channel, one English-language channel, and one information services channel.

There are three relatively new entrants into the Swazi media market: the magazines Youth Connexion and Siyavena and the television station Channel Swazi, but none are particularly critical of the state. The youth magazine aims mainly at addressing social issues affecting the youth such as HIV/AIDS and crime. Channel Swazi is also a pro-establishment medium that offers very little in terms of progressive and dynamic points of view. Siyavena is a sports publication without much critical content. Apart from adding its name to the media landscape, it has no new voice on behalf of media freedom in the kingdom.

\section{How independent are the media from government?}

There are estimated to be more than thirty pieces of legislation which could be regarded as restrictive to press freedom in Swaziland. These restrictions have a negative impact on the operations of the media. According to Vukani Maziya, these restrictive laws have resulted in lack of growth in the media industry, harassment and intimidation, strained relationships and 
mistrust between government and the media, weakened media organisations and lack of professionalism (Maziya 2003, pp.86-88).

Generally, in the state and private sector, the government has kept a tight reign on media censorship in recent years. A Commonwealth election monitoring team criticized Swaziland's lack of press freedom and expressed disappointment at government-owned Radio Swaziland's reporting on the 2003 elections, saying that restricted campaign coverage reduced voters' knowledge of the candidates and harmed their ability to hold candidates accountable (Campaign to Project Journalists 2003).

In April 2003, newly appointed Information Minister Abednego Ntshangase announced a censorship policy for state media, saying that, "the national television and radio stations are not going to cover anything that has a negative bearing on government". Ntshangase specifically indicated that state broadcasters would not be allowed to cover the controversy surrounding the government's plans to purchase a luxury jet for King Mswati (International Press Institute 2003).

The ban on negative content was directed toward the Swaziland Broadcasting and Information Services, which operates the only news-carrying radio channels in the country, and Swazi TV (Campaign to Project Journalists 2003).

In May 2006, King Maswati III banned newspapers from writing about his wives without his permission, even while covering official events, after the Times Sunday interviewed one of his wives (with her consent) while she was sick in hospital. This was the second time in 12 months that the Swazi king attempted to gag the media from reporting about royalty. In 2005 , he ordered the media to stop writing about his lavish spending after the media published that he had purchased US\$500 000 worth of luxurious vehicles for his 13 wives (Ndlovu 2006).

As well as overt censorship, self-censorship in Swaziland is enforced by unwritten cultural rules that restrict conduct. The media are often subjected to such often-ambiguous rules and their limitations. According to these rules, certain public figures and institutions are exempted from media and public scrutiny. These are enforced mostly by traditional authorities who have power to declare what is "unSwazi" and what is not. In a society that still holds strongly onto its culture, traditional and cultural rules force journalists to tread carefully and cautiously when conducting their duties (Mamba 2004, pp.99-101.)

The attitude of the media, especially at organisational level, seems to be one of acceptance that government is a stakeholder on national issues and that in spite of weaknesses apparent in both sides, coexistence and mutual co-operation is possible (Campaign to Project Journalists 2003).

Under Swazi law and custom there are issues that cannot be reported about King Mswati III. Maziya reports that many of the interplays between media ethics and Swazi law and custom have been due to the media reporting issues about the Royal family (Maziya, 2003 p.95).

When government fails to use the existing legislation to get at media houses and journalists, they turn to other means, such as in 1997 when government drafted a Media Council Bill (which was not enacted). Around the same time government announced the withdrawal of 
advertising from the Times of Swaziland to force it to be less critical of the government (Maziya 2003, p.98).

How representative are the media of different opinions and how accessible are they to different sections of society, including poor and vulnerable groups and political parties?

To test how representative the news media in Swaziland are, a content analysis of the kingdom's two daily newspapers, the Observer and the Times, was made.

All editions in the month of May 2005 were chosen, making a total of twenty editions of each newspaper.

The survey also took account of the criteria for the performance of news media identified earlier in this paper: those of informing the public and encouraging an active citizenry by achieving the public political goals of information, enlightenment, social criticism and exposing government arbitrariness (Ojo 2003; Tetty 2003; Roth 2001; Sparks 1991).

The content survey examined all editorial in the newspapers, which for the purpose of this research refers to all material that is not advertising. This includes news stories, feature articles and photographs and also material that may not have any news value at all (e.g. cartoons and horoscopes).

The types of editorial were grouped together into categories, a process simplified because both newspapers give labels to every editorial page (e.g. news, world news, entertainment, sport) and these labels were used for the content count. Where a page has editorial it is counted as a whole page irrespective of the amount of advertising that appears on the page. Table A contains the results. Only editorial categories that amounted to more than 1 percent of total editorial space were included in the table.

The number of pages per issue of the Times and Observer run from 36 to 48 and in the survey period the total number of pages in the Observer was 772, of which 144 were full pages of advertising (19 percent of total space), leaving 628 editorial pages to count. In the Times there were 816 pages in total of which 181 were full pages of advertising ( 22 percent of total space), leaving 635 editorial pages to count.

TABLE A: Number of editorial pages devoted to editorial types.

(Figures in brackets are rounded percentages of whole editorial content)

$\begin{array}{ll} & \text { Observer } \mathrm{n}=628 \\ \text { Analysis / comment } & 31(5) \\ \text { Business / farming } & 54(9) \\ \text { Community } & 3(-) \\ \text { Entertainment / leisure } & 97(15) \\ \text { Learning } & 12(2) \\ \text { Letters to editor } & 8(1) \\ \text { Motoring } & 3(-)\end{array}$

Times of Swaziland $n=635$

$15(2)$

$66(10)$

20 (3)

119 (19)

nil

9 (1)

7 (1) 
National news

Religion

Sport

World

Others
$188(30)$

9 (1)

180 (29)

$30(5)$

13 (2)
$236(37)$

nil

$136(21)$

$20(3)$

7 (1)

\section{Source: Author}

The results suggest that there are more similarities than differences between the editorial content of the Observer and the Times. Both place high emphasis on non-serious editorial material. For example, the combined "sport" and "entertainment and leisure" categories (the most non-serious material in the newspapers) equal 44 percent of total space in the Observer and 40 percent in the Times. The Observer has up to ten pages of sport per day (the Times has up to seven pages) and five pages of entertainments (the Times generally has six pages). By contrast serious comment and analysis averages only one and a half pages per day ( 5 percent) in the Observer and one page per day ( 2 percent) in the Times.

The entertainment and sport rely heavily on news from overseas (news of European soccer is particularly prevalent in both papers). "Entertainment" editorial includes news of overseas entertainment and in many cases it is not clear what the relevance the editorial has to Swazis as, for example, many of the movies and television shows that are featured will not be shown in Swaziland since the country has no cinemas and the TV shows do not air locally, not even on satellite.

The content of the "World" news is supplied by international agencies and in many cases the same news reports appear word for word in both newspapers (the same is true of world sport). In the Observer there is a greater concentration on news from other African countries and on some days an entire page is devoted solely to editorial from the continent.

The Observer has one category of editorial that the Times does not: "Learning". This category is a regular (at least once a week, sometimes more) feature that takes topics from school curricular and presents them in the form of lessons with coursework questions that readers can work on themselves. During the survey period lessons in mathematics, science and English were included in this feature.

\section{Survey of sources of news in two Swaziland newspaper titles}

To specifically test how accessible the print media are to different sections of society, including poor and vulnerable groups and political parties, a survey was made of the sources of the lead news items on each of the main news pages (front, three, five and seven) with a total of 80 stories counted.

TABLE B: Sources of news in two Swaziland newspaper titles

(Figures in brackets are rounded percentages) 


$\begin{array}{lll}\text { Source } & \text { Observer } & \text { Times of Swaziland } \\ & \mathrm{n}=80 & \mathrm{n}=80 \\ \text { Courts of law } & 1(1) & 8(10) \\ \text { Emergency services } & 4(5) & 11(14) \\ \text { Government (including } & 11(14) & 20(25) \\ \text { Parliament) } & & \\ \text { Locally based contacts } & 8(10) & 14(18) \\ \text { Monarchy } & 15(19) & 3(4) \\ \text { Press statements } & 18(23) & 14(18) \\ \text { Staged events } & 15(19) & 10(13) \\ \text { Others (inc adverts) } & 8(10) & \text { nil }\end{array}$

Source: Author

Both newspapers shared the same agenda, but the Observer gave greater prominence to the Monarchy, especially to reports (usually with several photographs, and sometimes the whole of page five) of the king or the king's mother undertaking various official activities.

The sources of the overwhelming majority of news reports in the newspapers are organized events, such as parliamentary sittings and staged events (public conferences and conventions) to which the media are invited (sometimes the only purpose of the event is to impart information to the media) and press statements. There are very few stories about ordinary people, unless they have been victims of misfortune or have appeared in court. This raises questions about the way the government dominates and who else within Swaziland is allowed to communicate through the news media. There are some exceptions to this: locally-based stories of human interest (crime, violence, suicide) appear to have come from local sources rather than been fed to reporters by the police or emergency services.

We should be interested in the relationship between journalists and their sources because everyone should have equal access to the media. We should be concerned with relations between the media and those who have political and ideological power and especially institutions that seek to define and manage the flow of information in contested fields of discourse (Schlesinger 1990, pp.62-66). The traditional liberal view has it that in a democracy the media reflects a wide range of opinions and interests in society. That position is contested by Hall et al (1980) who argue that people in powerful positions are able to over access the media and become "primary definers" of the news because journalists faithfully reproduce what they say and thus reinforce the existing structure of power in society. The primary definers are allowed to set the agenda and others with opposing views have to insert themselves into its definition of what is at issue. In this way, Hall argues, the dominant ideology of the ruling elite is transmitted by the media (Hall et al 1980, p.58).

Generally, news reports in the Swazi newspapers are presented at face value. Reporters tend not to ask questions that require people in positions of power to justify their statements or actions. Reporters tend to receive information from a single source and re-present it unquestioningly in reports, which may be a consequence of the inexperience of journalists in Swaziland (see also section on capacities of journalists below). In most of the stories in the survey, the reporter made no attempt to gather additional information, not even to get a balancing quote in the case of a story about a matter of controversy. Nor do journalists tend to 
give background information to the stories, even those running from day to day. They seem to have no institutional memory and are unable to draw on information from their own archives to put stories into context.

One of the traits of Swazi journalism is its unwillingness to produce stories that contain a balance of views within them. Instead, journalists opt for revisiting stories over a period of time, introducing new elements and different views in each new episode. In this way committed readers might be able to piece together the disparate elements of the story into a comprehensible whole. But each new episode tends to include only one source, thus there is no balance of views or attempt at interrogation of the powerful. This demonstrates a lack of capacity among Swazi journalists to perform one of their vital roles within a democracy, which is to examine what government is and is not doing and to provide the public with information, comment, analysis, criticism and alternative views.

The two newspapers are published in an elite language, English, and that fact alone excludes many non-English reading people from their contents, but even the use of the English language is problematic as journalists do not use clear and simple language in their reports and articles. They often simply repeat the jargon of the press release or press statement and sometimes the stories are rendered unintelligible to even the most literate reader, suggesting that reporters do not themselves understand what they are writing and simply copy down the official words.

A columnist on the Weekend Observer has noted that some people have worked in newsrooms for 15 years and still not mastered the art of writing and this is exemplified in headlines to news reports that often promise much more than the reports deliver (Bongiwe Zwane 2005, p.17).

What are the capacities of Swazi journalists and where might there be areas for improvement?

Media practitioners in Swaziland are generally scathing about the capacity of their profession to deliver good journalism. The media in Swaziland are partisan, inaccurate and generally unprofessional (Maziya, 2003, p.97) and they are slowly turning into an irrelevant vehicle in public discourse (Makhubu 2005, p.15).

A workshpp of civic society stakeholders held in September 2005 which attempted to measure the performance of the media in Swaziland reported that news media lacked credibility and many people saw journalists as lacking in education and experience (Motsa 2005, p.7).

The print media in Swaziland falls some way short of meeting the public political objectives that help to foster good governance.

Content in the Swazi print media is compromised by a lack of professionalism in writing, editing and positioning of news articles in the newspapers to the extent of weakening their retainer value. Interesting news stories are watered down by the incomprehensible way they are written, leaving the reader confused and bewildered (Sibisi 2005, pp.12-14).

One of the biggest concerns about the media is the quality of news that makes it to the news pages. Bheki Makhubu, editor of the Nation magazine, believes sex and murder have become 
the only events that make the front pages in the newspapers today. He reports that issues of national importance like the writing of the new Swaziland Constitution and the rampant corruption in government are rarely, if ever, reported on. News analysis no longer exists even though the Observer has more columnists today than at any other time in its history (Makhubu 2005, p.15).

Newsrooms have become fearful of lawsuits - aggrieved people issue lawsuits regardless of whether that person has really been defamed. This has resulted in the erring on the side of caution, banning publication of all articles that could raise controversy (Ibid 2005, p.15).

Lunga Masuku, publisher of Youth Connexion magazine, says junior editors have no nose for news and concentrate on petty things while ignoring the problems faced by society. Media houses believe that when they run serious stories about the Swazi Constitution on the front page people do not buy the paper. They buy the paper when there are sex stories (Masuku 2005, p.16).

Opinion pieces have become the order of the day and this exposes readers to un-researched opinion pieces that have compromised journalistic standards (Ibid p.16).

Editors suppress some stories because they are not in favor of them. Other sections of society are denied having their voices heard simply because the editor of the day does not believe in those persons' point of view (Ackel Zwane 2005, pp.10-11).

Masuku says most of the reporters can hardly write a story and they only survive on handouts in the form of press releases and can hardly generate their own story ideas (Masuku 2005 p.16).

Journalists suffer harassment, intimidation and sanctions which, according to Vukani Maziya, chief executive of Swazi Television, has made many of them complacent (Maziya 2003, p.95). As a result Maziya identifies an increase in "conveyor belt" journalism where journalists rewrite speeches by officials and ministers with a decline in in-depth analysis and investigative reporting. According to Maziya, " the legal environment poses many risks to vibrant, creative and innovative journalists: it is a good home for those who will succumb" (Maziya 2003, p.97).

External political and economic pressure comes from government and big business. Typical examples of the government's ruthlessness were its abrupt shutdown of the Observer in early 2000 and the Guardian Weekly Newspaper the following year (Sibisi 2005, pp.12-14).

Government also uses a subtle policy of assimilation through which it rewards those journalists who toe the line with political positions or as ministerial private secretaries. This has engendered a culture of self-censorship from the cub reporter to the editor (Sibisi 2005 pp.12-14).

Some journalists willingly work as propagandists, especially at the SBIS radio, according to Times columnist Vusi Sibisi. He identifies a belief among journalists that they see their role as propagandists of the government of the day. As a result listeners believe SBIS radio is used as a weapon for the government to attack its adversaries. Some radio journalists have appropriated to themselves the prerogative to decide who is and who is not an enemy of the 
state and the government and have made themselves the attack dogs whenever someone criticises government (Sibisi 2005, pp.12-14).

Economic pressures also impact on the quality of journalistic output. In Swaziland the media have very little to offer in terms of professional and economic growth as a result there is a brain drain where journalists quit for better employment opportunities. A report by LKM Attorneys noted 68 percent of industry employees were aged between 26 and 40 (cited in Maziya 2003, p.97).

The exodus of the best qualified and experienced personnel has led to the "juniorization" of newsrooms whereby the less good young and inexperienced journalists, often untrained and seriously lacking in skills and competence, are left to staff the newsrooms and occupy high editorial positions. They work under extreme pressure without the guidance of senior staff (Motsa 2005, p.7; Lushaba 2005, pp.8-9; Bongiwe Zwane 2005, p.17).

The media houses make no effort to improve the skills of staff as the president of the Swaziland National Association of Journalists, Alec Lushaba, noted, "Even in this day and age, anybody can still walk into the newsroom and claim to be a journalist" (Lushaba 2005, pp.8-9).

The scarcity of resources in the media houses makes it difficult for journalists to gain insight and to specialise in specific areas of journalism. There is a lack of continuous in-house and further training, and lack of transparency on upward mobility opportunities and security of tenure in the journalism industry. These weaknesses result in contextual weaknesses, especially in newspapers, because of a reliance on running news stories to the detriment of investigative, engaging and incisive thought-provoking in-depth analysis and commentaries (Sibisi 2005, pp. 12-14).

There is no longer investigative journalism because there is too much fear in newsrooms with journalists intimidated and threatened into submission. Because the media have become so docile and timid public officials have grown arrogant and are doing as they please because they are no longer afraid of the press. Public officials and politicians have no fear of the media and they bully media practitioners into toeing the line while corruption and many wrongs go unchecked (Motsa 2005, p.7; Makhubu 2005 p.15).

The news editor of the Observer, Ackel Zwane, believes the lack of adherence to media ethics is a major challenge to editors. National organisations guiding the practice of journalists in the country have not been committed to training journalists about the work ethic of the profession. There is a need to train journalists on media ethics editorial responsibility; accountability and respect of the rights of the public journalists serve (Ackel Zwane 2005, pp. 10-11).

The young editors enter into relationships with their sources. This relationship is mainly financial under the guise that the profession does not pay. There is also evidence that female journalists have to give sexual favours to editors in order to get their stories into the newspapers (Ackel Zwane 2005, pp.10-11; Masuku 2005, p.16).

\section{Concluding remarks}


This review of Swazi newspapers set out to examine the extent to which they are able to encourage and foster good governance. On any objective standard the newspapers are found wanting but there are a number of mitigating factors. The country is not a democracy and journalists are harassed if they try to write and publish material that offends the king and his government. There is little that can be done about this so long as the king continues to hold absolute powers. The Swazi Constitution signed into law in 2006 does nothing to diminish these powers.

The international community should exert pressure on the kingdom to allow the media proper editorial freedom with legislation to protect and promote the public interest. The public interest should extend beyond the interest of powerful groups to include the poor, powerless and voiceless. It might be that in a kingdom such as Swaziland, the printed press is not the best vehicle to achieve this and instead radio should be extended by dismantling the state controlled SBIS and encouraging the creation of small, community-run stations that are better able to allow for the expression of a range of opinions of public concern.

Commercial media, based on advertising, would have a limited impact in Swaziland since the majority of people are too poor to be attractive to advertisers and those people advertisers might seek out are concentrated in urban areas and are likely to speak English. It is reasonable to suppose that stations broadcasting to such audiences would not seek out the rural poor. Experience elsewhere also suggests that such stations would fill their airtime with light entertainment rather than serious public interest content and that competition for audiences would force all stations to follow suit (Roth 2001, p.13).

Journalists identified a need for practitioners with higher levels of writing, technical and intellectual skills. This leads to a conclusion that training might help improve capacities. The kingdom's only university, the University of Swaziland (UNISWA), has run a three year full time diploma in journalism and mass communication for nine years and many of its graduates have taken posts in the media industry. After consultation with media stakeholders UNISWA is preparing to extend opportunities for education and training in journalism. Central to its plans is the requirement that courses are sensitive to local needs and also that graduates are capable of making complicated topics accessible to their audiences. Despite UNISWA's efforts the Swazi media industry needs to provide regular training for its own staffs to update skills and competencies.

There is still a lot of work to be done.

\section{REFERENCES}

Campaign to Project Journalists. 2003, Attacks On The Press. Cpj.org. Retrieved February 20, 2006 from http://www.cpj.org/attacks03/africa03/swazi.html.

Curran, J. 2002, Media Power. Routledge London. 
Department for International Development. 2001, Making Government Work for Poor People: Building State Capability. Strategies for Achieving the International Development Targets, DfID, London.

Feustel, M., Germain, O., Matus, L., Reuchlin, P., \& Ridley, B. n.d., Free Press and Good Governance in Southern Africa: Media Assistance and Free Press Advocacy in Member States of the Southern African Development Community: Mapping Roles and Relationships. Stanhope. Retreived 31 May, 2006 from www.stanhopecentre.org/research/mdps_southafrica.doc

Habermas, J. 1989, The Structural Transformation of the Public Sphere, Polity, Cambridge.

Hall, S., Chrichter, C., Jefferson, T., Clarke, J. \& Roberts, B. 1978, Policing the Crisis: Mugging, the State, and Law and Order, Macmillan, London.

International Crisis Group. 2005, Swaziland: the Clock is Ticking. Africa Briefing No. 2. ICG, Pretoria / Brussels.

International Press Institute. 2003, World Press Freedom Review. Retrieved February 20, 2006 from http://www. freemedia.at/wpfr/Africa/swazi.htm\#2003

Lushaba, A. 2005, 'Where Have We Lost It?', Khulumani, Issue 6, pp.8-9.

Makhubu, B. 2005, 'Our Media Has Become Too Fearful', Khulumani, Issue 6, p.15.

Mamba, S. 2004, 'Swaziland' in So This Is Democracy?, ed. Media Institute of Southern Africa, MISA, Windhoek.

Masuku, L. 2005, 'The Shenanigans in Our Noble Profession', Khulumani, Issue 6, p.16. 
Maziya, V. 2003, 'Swazi Media: a Bridge Over Troubled Waters: Journalistic Views on Restrictive Media Laws', in Restrictive Media Laws in Swaziland, ed. T. Khumal, Media Institute of Southern Africa, Swaziland Chapter.

Motsa, M. 2005, 'State of the Media in SD', Khulumani, Issue 6, p.7.

Ndlovu, N. 2006, May 9. 'Swaziland: King Mswati III Gags the Media', African News Dimension. Retrieved 31 May, 2006 from http://www.andnetwork.com/index;jsessionid=51423FC9FB14EAECAE5B9A49863101DF? service $=$ direct $/ 1 /$ StoryList/item.viewStory $\&$ sp $=133938$

Ojo, E. 2003, 'The Mass Media and the Challenges of Sustainable Democratic Values in Nigeria: Possibilities and Limitations', Media, Culture \& Society, vol. 25, no.6, pp.821-840.

Olaleye, W. 2003, October. 'Socio Economic Profile', in Swaziland Election Dossier, Issue 1, pp.6-9, Electoral Institute of Southern Africa, Auckland Park.

Price, M \& Krug, P. 2002, The Enabling Environment for Free and Independent Media, USAID,. Washington DC.

Roth, C. 2001, The Media in Governance: a Guide to Assistance. Developing Free and Effective Media to Serve the Interests of the Poor, Department for International Development, London.

Schlesinger, P. 1990, 'Rethinking the Sociology of Journalism: Source Strategies and the Limits of Media Centrism', in Public communications, the new imperatives, ed M. Ferguson, Sage, London.

Sibisi, V. 2005, 'Need for a Major Surgery on Swazi Media', Khulumani, Issue 6, pp.12-14. 
Skinner, D. Gasher, M. Compton J. (2001). Putting Theory to Practice: a Critical Approach to Journalism Studies, Journalism 2(3), pp.341-360.

Southern African Development Community. 2004, Media Law, a Comparative Overview of Media Laws and Practice in Botswana, Swaziland and Zambia, Konrad Adenauer Foundation, Johannesburg.

Sparks, C. 1991, 'Goodbye Hildy Johnson, the Vanishing "Serious Press"', in

Communications and Citizenship, eds, P. Dahlgren. \& C. Sparks, Routledge, London.

Tetty, W. J. 2003, 'The Media and Democratization in Africa: Contributions, Constraints and Concerns of the Private Press. Media, Culture \& Society, vol. 23, no. 1, 5-31.

Thomas, R. 2000, Industry Influences on Journalism Training: Thoughts for the Future. Paper delivered at the Journalism Educators Association of New Zealand Conference, Christchurch, New Zealand.

Zwane, A. 2005, 'Challenges Facing the Young Editor', Khulumani, Issue 6, pp.10-11.

Zwane, B. 2005, 'Journalism: It's Either You Swim or Sink', Khulumani, Issue 6, p.17. 